\title{
Prevalence of geohelminths on edible fruits and vegetables cultivated in rural villages of Ebonyi State, South East Nigeria
}

\author{
Michael O. Elom, *Ukpai A. Eze, Amos Nworie, Irene O. Akpotomi. \\ Department of Medical Laboratory Science, College of Health Sciences, Ebonyi State \\ University, P. M. B. 053, Abakaliki, Nigeria.
}

\begin{abstract}
Chronic and intense geohelminth infections can contribute to malnutrition, iron-deficiency anaemia, morbidity and sometimes, affecting cognitive process, and provoking intestinal obstruction or rectal prolapse. The prevalence of geohelminths on edible fruits and vegetables cultivated in rural villages of Ebonyi State, Nigeria was determined in this study. A total of 250 samples (five per product from each market) were examined for contamination by geohelminths using sedimentation and floatation methods. One hundred and one (40.4\%) of the two hundred and fifty (250) fruits and vegetables were positive for geohelminths microscopically. Among the fruits, pineapple had the highest number of geohelminths, 18(72\%) while Pawpaw had the lowest, $13(12 \%)$. And among the vegetables, water leaf had the highest number of geohelminths 16 (64 $\%)$ while bitter leaf had the lowest number of geohelminths, 7 (28\%). Geohelminths identified were ova of Ascaris lumbricoides (54.5\%), Strongyloides stercoralis (6.9\%), ova of Hookworm (23.8\%), Trichuris Trichiura (8.9\%), Enterobius vermicularis (5.9\%). This study shows high level of fruits and vegetables contamination with geohelminths in the study area. This portends a great risk of acquiring intestinal parasites by eating improperly washed fruits and vegetables.
\end{abstract}

Keywords: Geohelminths, Fruits, Vegetables, Contamination, Malnutrition.

\section{INTRODUCTION}

Geohelminths (soil-transmitted helminths) are a group of nematode parasites with an essential phase of their asexual lifecycle in the soil. There is a period of persistence in the soil during which the infective stages are protected and preserved. Geohelminth infections are most prevalent in tropical and subtropical regions of the developing world, where adequate water and sanitation are lacking (De Silva et al., 2003). Recent estimates suggest that Ascaris lumbricoides infects over one billion people, Trichuris trichuria infects 79 millions and hookworm (Ancyclostoma duodenale and Necator americanus) infects 740 million people (WHO, 2008). Chronic and intense geohelminth infections can contribute to malnutrition, iron-deficiency anaemia, morbidity and sometimes, health-comprising nutritional status, affecting cognitive process, which include tissue reaction such as granuloma and provoking intestinal obstruction or rectal prolapse (Adeyegba and Akinlabi, 2002; Etim et al., 2002; Ezeamama et al., 2005).

Indigenous fruits and vegetables are known to play major role in the nutritional livelihood of the Nigerian population, especially in the rural areas where there is poor socio-economic condition (Adeboye and Adedayo , 2008). Fruits and vegetables are good sources of mineral elements such as iron, and vitamins, including vitamin C, Vitamin B12, Niacin and Riboflavin. Consumption of raw or unhygienically prepared vegetables is considered a risk factor for human parasitic infections (Orlandi et al., 2002). The climate and topography of the rural villages in Ebonyi State, South-East Nigeria is suitable for the growth of these fruits and vegetables throughout the year. Rain during wet season and irrigation during dry season encourage their growth all year round. These two sources of water are highly polluted with human and animal faeces which represent high risk to farmers and consumers of fruit and vegetable products. Market fruits are often contaminated by eggs of human intestinal nematodes where human and animal faeces are extensively used as fertilizers and reused waste water. The indirect reserve of river water contains a substantial percentage of municipal refuse and sewage. This practice is growing prominence in Nigeria as a result of the growing cost of mineral fertilizer and high demand of basic fruits and vegetables as a nutrient diet due to poor socioeconomic conditions (Damen et al., 2007). Epidemiological studies have indicated that areas 
characterized by endemic helminthic diseases are found in population where raw untreated waste water is used for irrigation of fruits and vegetables and consumption of such waste irrigated fruits are generally done unwashed or uncooked (Brooker, 2003; Nock et al., 2003; Naish et al., 2004). Ethnic eating habits, poverty, and environmental degradation have also contributed to the emergence of geohelminth infections worldwide (Phiri et al., 2000). Some of these infections may have been acquired from food especially raw fruits and vegetables, water and animals.

This study was therefore, designed to determine the prevalence of geohelminths on edible fruits and vegetables cultivated in rural villages of Ebonyi State, South-East Nigeria and to identify the fruits and vegetables which carries the greater risk of geohelminth infection.

\section{MATERIALS AND METHODS}

Collection of fruits and vegetables: Five different types of fruits and five different types of vegetables were sampled from five major markets in rural villages of Ebonyi State, South East Nigeria, giving a total of 250 samples of fruits and vegetables. These markets were selected because majority of the populace depend on them for the supply of fruits and vegetables. The different types of fruits and vegetables sampled are shown in table 1.

Table 1: $\quad$ Types of Fruits and Vegetables sampled.

\section{S/NO FRUITS SCIENTIFIC NAMES VEGETABLES SCIENTIFIC NAMES}

\begin{tabular}{cllll}
\hline 1 & Pineapple & Anana Comosus & Pumpkin Leaf & Telfairia \\
2 & Orange & Citrus Sinensis & Water Leaf & Talinum Trangulare \\
3 & Paw Paw & Carica Papaya & Green Leaf & Amaranthus Spinosus \\
4 & Banana & Musa Acuminata & Garden Egg & Melongena \\
& & Leaf & \\
5 & Water Melon Citrullus Lanatus & Bitter Leaf & Vernonia Amigdalina
\end{tabular}

Specimen Analysis: The parasitological analysis of these products was carried out at the Department of Medical Laboratory Science Research Laboratory, Ebonyi State University, Abakaliki, Nigeria. The fruits and vegetables were analysed in the laboratory using both the sedimentation and flotation techniques.

Sedimentation Method: $250 \mathrm{~g}$ samples of each fruits and vegetables were washed in distilled water in a sterile beaker for the removal of the parasitic ova, larva or cysts. The suspension was strained through a sterile sieve to remove undesirable materials (Nyarango et al., 2003). The filtrate was centrifuged at $3000 \mathrm{rpm}$ for 15 minutes (Damen et al., 2007) and the supernatant was discarded into the disinfectant jar. The sediment was mixed up and a drop was applied on the centre of a clean grease-free microscope slide and a clean cover slip was placed gently to avoid air bubbles and over-flooding. The preparation was examined under microscope for parasites using $\mathrm{X} 10$ and $\mathrm{X} 40$ objectives.

Floatation Method: $250 \mathrm{~g}$ samples of each fruits and vegetables were washed in distilled water in a sterile plastic container for the removal of parasitic ova, larva or cysts. The suspension was strained through a sterile sieve to remove undesirable materials (Nyarango et al, 2003). The filtrate was centrifuged at $3000 \mathrm{rpm}$ for 15 minutes and the supernatant was discarded into the disinfectant jar. The sediment obtained was re- suspended in zinc sulphate floatation fluid and re-centrifuged. The floatation fluid 
was added to fill to the brim and a cover slip was super-imposed on it. The cover slip was lifted and examined under microscope using $\mathrm{X} 10$ and $\mathrm{X} 40$ objectives.

\section{RESULTS}

Five different types of fruits and five different types of vegetables were sampled from five different markets in rural villages of Ebonyi State, South East Nigeria. A total of 250 samples were examined for prevalence of geohelminths. Table 2 shows the geohelminthic profile of each fruit and vegetable sample examined in five markets. $101(40.4 \%)$ of the 250 fruits and vegetables were positive for prevalence of geohelminths microscopically. Among the fruits, pineapple had the highest number of geohelminths $18(72 \%)$ while the lowest was pawpaw 3(12\%). And among the vegetables, water leaf had the highest number of geohelminths $16(64 \%)$ while the lowest was bitter leaf $7(28 \%)$. Table 3 shows the prevalence of geohelminths on fruits and vegetables from each market. The highest prevalence of geohelminths was seen at Okwo Ngbo market $(50 \%)$,followed by Nkalagu market (48\%) and lboko market $(40 \%)$ while the lowest was from Eke Aba market (28\%). Table 4 shows the frequency of geohelminths isolated on fruits and vegetables in various markets.

Table 2. Table 2: Number Of Fruits And Vegetables Contaminated With Geohelminths In Each Market.

\begin{tabular}{|c|c|c|c|c|c|c|c|c|}
\hline $\mathbf{S} / \mathbf{N}$ & $\begin{array}{l}\text { Fruits } \& \\
\text { Vegetables }\end{array}$ & $\begin{array}{l}\text { OKwo Ngbo } \\
\text { Market }\end{array}$ & $\begin{array}{l}\text { Eke Ezza } \\
\text { Market }\end{array}$ & $\begin{array}{l}\text { Iboko } \\
\text { Market }\end{array}$ & $\begin{array}{l}\text { Nkalagu } \\
\text { market }\end{array}$ & $\begin{array}{l}\text { Eke Aba } \\
\text { Market }\end{array}$ & $\begin{array}{c}\text { Number } \\
\text { Examined } \\
(y) \\
\end{array}$ & $\begin{array}{l}\text { Number (\%) } \\
\text { Positive For } \\
\text { Geohelminths } \\
(\mathrm{x})\end{array}$ \\
\hline 1 & Pineapple & 5 & 5 & 5 & 5 & 5 & 25 & $18(72 \%)$ \\
\hline 2 & Orange & 5 & 5 & 5 & 5 & 5 & 25 & $8(32 \%)$ \\
\hline 3 & Paw paw & 5 & 5 & 5 & 5 & 5 & 25 & $3(12 \%)$ \\
\hline 4 & Banana & 5 & 5 & 5 & 5 & 5 & 25 & $6(24 \%)$ \\
\hline 5 & Water Melon & 5 & 5 & 5 & 5 & 5 & 25 & $4(16 \%)$ \\
\hline 6 & Pumpkin Leaf & 5 & 5 & 5 & 5 & 5 & 25 & $15(60 \%)$ \\
\hline 7 & Water Leaf & 5 & 5 & 5 & 5 & 5 & 25 & $16(64 \%)$ \\
\hline 8 & Green Leaf & 5 & 5 & 5 & 5 & 5 & 25 & $10(40 \%)$ \\
\hline 9 & Garden Egg Leaf & 5 & 5 & 5 & 5 & 5 & 25 & $14(56 \%)$ \\
\hline 10 & Bitter Leaf & 5 & 5 & 5 & 5 & 5 & 25 & $7(28 \%)$ \\
\hline & TOTAL & 50 & 50 & 50 & 50 & 50 & 250 & $101(40.4 \%)$ \\
\hline
\end{tabular}

Table 5 shows the overall frequency of geohelminths isolated from 250 samples of fruits and vegetables in this study. The overall frequency of isolated geohelminths was Ascaris lumbricoides 55(54.5\%), Ova of Hookworm 24(23.8\%), Trichuris Trichiura 9(8.9\%), Strongyloides stercoralis $7(6.9 \%)$ and Enterobius vermicularis $6(5.9 \%)$.
Table 6 shows the comparison between the two different methods employed i.e. Sedimentation method and Floatation method. Sedimentation technique recovered the highest number of geohelminths $87(86.1 \%)$ while floatation technique recovered only $14(13.9 \%)$. 
Table 3: Prevalence of Geohelminths on Fruits and Vegetables from Each Market.

\begin{tabular}{|c|c|c|c|c|c|c|c|c|c|c|}
\hline \multirow{2}{*}{$\begin{array}{l}\text { Fruits } \& \\
\text { Vegetables }\end{array}$} & \multirow{2}{*}{ 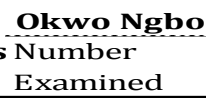 } & \multirow{2}{*}{$\begin{array}{l}\text { Market } \\
\begin{array}{l}\text { Number } \\
\text { Positive }\end{array}\end{array}$} & \multirow{2}{*}{$\begin{array}{l}\text { Eke Ezza } \\
\text { Number } \\
\text { Examined }\end{array}$} & \multirow{2}{*}{$\begin{array}{l}\text { Market } \\
\text { Number } \\
\text { Positive }\end{array}$} & \multicolumn{2}{|c|}{ Iboko Market } & \multicolumn{2}{|c|}{ Nkalagu Market } & \multicolumn{2}{|c|}{ Eke Aba Market } \\
\hline & & & & & $\begin{array}{l}\text { Number } \\
\text { Examined }\end{array}$ & $\begin{array}{l}\text { Number } \\
\text { Positive }\end{array}$ & $\begin{array}{l}\text { Number } \\
\text { Examined }\end{array}$ & $\begin{array}{l}\text { Number } \\
\text { Positive }\end{array}$ & $\begin{array}{l}\text { Number } \\
\text { Examined }\end{array}$ & $\begin{array}{l}\text { Number } \\
\text { Positive }\end{array}$ \\
\hline Pineapple & 5 & 4 & 5 & 3 & 5 & 3 & 5 & 4 & 5 & 4 \\
\hline Orange & 5 & 2 & 5 & 2 & 5 & 1 & 5 & 2 & 5 & 1 \\
\hline Pawpaw & 5 & 1 & 5 & 1 & 5 & 1 & 5 & o & 5 & o \\
\hline Banana & 5 & o & 5 & 2 & 5 & 1 & 5 & 3 & 5 & $\mathbf{O}$ \\
\hline $\begin{array}{l}\text { Water } \\
\text { melon }\end{array}$ & 5 & 2 & 5 & $\mathbf{O}$ & 5 & 1 & 5 & $\mathbf{o}$ & 5 & 1 \\
\hline $\begin{array}{l}\text { Pumpkin } \\
\text { Leaf }\end{array}$ & 5 & 4 & 5 & 2 & 5 & 3 & 5 & 4 & 5 & 2 \\
\hline Water Leaf & 5 & 4 & 5 & 3 & 5 & 4 & 5 & 3 & 5 & 2 \\
\hline Green Leaf & 5 & 3 & 5 & 2 & 5 & 2 & 5 & 2 & 5 & 1 \\
\hline $\begin{array}{l}\text { Garden Egg } \\
\text { Leaf }\end{array}$ & 5 & 2 & 5 & 3 & 5 & 3 & 5 & 4 & 5 & 2 \\
\hline Bitter Leaf & 5 & 3 & 5 & o & 5 & 1 & 5 & 2 & 5 & 1 \\
\hline Total & 50 & 25 & 50 & 18 & 50 & 20 & 50 & 24 & 50 & 14 \\
\hline Percentage & & $50 \%$ & & $36 \%$ & & $40 \%$ & & $48 \%$ & & $28 \%$ \\
\hline
\end{tabular}

Table 4: Frequency of geohlminths isolated on fruits and vegetables in various markets.

\begin{tabular}{|c|c|c|c|c|c|c|c|c|c|c|c|}
\hline Markets & $\begin{array}{l}\text { Isolated } \\
\text { Geo } \\
\text { helminth } \\
\end{array}$ & $\begin{array}{l}\text { Pineapple } \\
(\%)\end{array}$ & $\begin{array}{c}\text { Orange } \\
(\%)\end{array}$ & $\begin{array}{c}\text { Pawpaw } \\
(\%) \\
\end{array}$ & $\begin{array}{c}\text { Banana } \\
(\%)\end{array}$ & $\begin{array}{c}\text { Water } \\
\text { Molon } \\
(\%) \\
\end{array}$ & $\begin{array}{l}\text { Pumpkin } \\
\text { Leaf } \\
(\%)\end{array}$ & $\begin{array}{c}\text { Water } \\
\text { Leaf } \\
(\%)\end{array}$ & $\begin{array}{c}\text { Green } \\
\text { Leaf } \\
(\%) \\
\end{array}$ & $\begin{array}{c}\text { Garden } \\
\text { Egg Leaf } \\
(\%) \\
\end{array}$ & $\begin{array}{c}\text { Bitter } \\
\text { Leaf } \\
(\%) \\
\end{array}$ \\
\hline Okwo & $\mathrm{A}$ & $2(40)$ & $2(40)$ & & & & $2(40)$ & $1(20)$ & $1(20)$ & $2(40)$ & $2(40)$ \\
\hline Ngbo & $\mathrm{S}$ & & & $1(20)$ & & & & & & & \\
\hline \multirow[t]{4}{*}{ Market } & $\mathbf{H}$ & $2(40)$ & & & & $2(40)$ & $2(40)$ & $2(40)$ & $1(20)$ & & \\
\hline & $\mathbf{T}$ & & & & & & & & & & $1(20)$ \\
\hline & E & & & & & & & $1(20)$ & $1(20)$ & & \\
\hline & A & $2(40)$ & $2(40)$ & & $2(40)$ & & & $2(40)$ & $2(40)$ & $2(40)$ & \\
\hline Eke Ezza & $\mathrm{S}$ & & & & & & & & & $1(20)$ & \\
\hline \multirow[t]{3}{*}{ Market } & $\mathbf{H}$ & $1(20)$ & & & & & $2(40)$ & $1(20)$ & & & \\
\hline & $\mathbf{T}$ & & & $1(20)$ & & & & & & & \\
\hline & $\mathbf{E}$ & & & & & & & & & & \\
\hline & A & $2(40)$ & $1(20)$ & & $1(20)$ & $1(20)$ & $2(40)$ & $2(40)$ & $1(20)$ & $2(40)$ & \\
\hline Iboko & $\mathrm{S}$ & & & & & & & & & $1(20)$ & \\
\hline \multirow[t]{5}{*}{ Market } & $\mathbf{H}$ & $1(20)$ & & $1(20)$ & & & $1(20)$ & $1(20)$ & & & \\
\hline & $\mathbf{T}$ & & & & & & & & $1(20)$ & & $1(20)$ \\
\hline & $\mathbf{E}$ & & & & & & & $1(20)$ & & & \\
\hline & A & & $2(40)$ & & $1(20)$ & & $2(40)$ & $2(40)$ & & $2(40)$ & $1(20)$ \\
\hline & $\mathrm{s}$ & $1(20)$ & & & $2(40)$ & & & & & & \\
\hline Nkalagu & $\mathbf{H}$ & $3(60)$ & & & & & $1(20)$ & & & & \\
\hline \multirow[t]{4}{*}{ Market } & $\mathbf{T}$ & & & & & & & $1(20)$ & & $2(40)$ & $1(20)$ \\
\hline & $\mathbf{E}$ & & & & & & $1(20)$ & & $2(40)$ & & \\
\hline & A & $2(40)$ & $1(20)$ & & & & $2(40)$ & $2(40)$ & & $2(40)$ & \\
\hline & $\mathrm{S}$ & & & & & & & & & & $1(20)$ \\
\hline Eke Aba & $\mathbf{H}$ & $2(40)$ & & & & $1(20)$ & & & & & \\
\hline \multirow[t]{2}{*}{ Market } & $\mathbf{T}$ & & & & & & & & $1(20)$ & & \\
\hline & $\mathbf{E}$ & & & & & & & & & & \\
\hline
\end{tabular}

A ............ Ova of Ascaris Lumbricoides

S ............. Larva of Stongyloides Stercoralis

H .............. Ova of Hookworm

T .............. Ova of Trichuris Trichiura

E .............. Ova of Enterobius Vermicularis 
Am. J. Food. Nutr, 2012, 2(3): 58-64

Table 5: Frequency of Isolated Geohelminths.

\begin{tabular}{lcc}
\hline Geohelminths & Frequency & Percentage \\
\hline Ova of Ascaris Lumbricoindes & 55 & $54.50 \%$ \\
Strongyloides Stercoralis & 7 & $6.90 \%$ \\
Ova of Hookworm & 24 & $23.80 \%$ \\
Trichuris Trichiura & 9 & $8.90 \%$ \\
Enterobius Vermicularis & 6 & $5.90 \%$ \\
\hline Total & $\mathbf{1 0 1}$ & $\mathbf{1 0 0 \%}$ \\
\hline
\end{tabular}

Table 6: Comparison of The Two Techniques Employed.

\begin{tabular}{lcccc}
\hline Geohelminths & $\begin{array}{c}\text { Sedimentation } \\
\text { Method }\end{array}$ & Fercentage & $\begin{array}{c}\text { Flotation } \\
\text { Method }\end{array}$ & Percentage \\
\hline Ova of Ascaris Lumbricoides & 45 & $81.80 \%$ & 10 & $18.20 \%$ \\
Strongyloides Stercoralis & 7 & $100 \%$ & 0 & $0 \%$ \\
Ova of Hookworm & 21 & $87.50 \%$ & 3 & $12.50 \%$ \\
Trichuris Trichiura & 8 & $88.90 \%$ & 1 & $11.10 \%$ \\
Enterobius Vermicularis & 6 & $100 \%$ & 0 & $0 \%$ \\
\hline Total & $\mathbf{8 7}$ & $\mathbf{8 6 . 1 0 \%}$ & $\mathbf{1 4}$ & $\mathbf{1 3 . 9 0 \%}$ \\
\hline
\end{tabular}

\section{DISCUSSION}

Geohelminthic infections have received little attention in developing countries. As a rule, these organisms contaminate fruits and vegetables while still on the field and are usually transmitted by contaminated water and spread by ineffective hygienic practice (Silvia et al, 2007). A total number of 250 samples of edible fruits and vegetables were examined. Out of the 250 samples, 101(40.4\%) were positive for 
geohelminths. Pineapple recorded the highest number $(72 \%)$ while pawpaw recorded the least geohelminthic contamination (12\%) among the fruits . And among the vegetables, water leaf had the highest number of geohelminths $(64 \%)$ while the lowest was bitter leaf (28\%). This result is similar to the study carried out by Uneke, (2004) who reported that of the 34 ova isolated from fruits, 30 were positive for Pineapple.

Results from this study shows that Okwo Ngbo market recorded the highest prevalence $(50 \%)$ of geohelminths, followed by Nkalagu market (48\%) and lboko market (40\%). Eke Ezza market had (36 $\%)$ while Eke aba market recorded (28\%). The high prevalence of geohelminths on fruits and vegetables are due to the fact that these open markets were characterized by the presence of refuse dumping sites nearby, poor drainage, improper disposal of faeces from the children of traders and poor hygienic practice. These products were brought in from rural areas around these markets.

Five different types of geohelminths were isolated from 250 samples of edible fruits and vegetables collected from these markets. These parasites include Ova of Ascaris lumbricoides 55(54.5\%), Strongyloides Stercoralis 7(6.9\%), Ova of Hookworm 24(23.8\%), Trchuris Trichiura 9(8.9\%) and Enterobius vermicularis 6(5.9\%). However, the geohelminths isolated from this study differ from those isolated from other parts of Nigeria (Adeyegba and Akinlabi, 2002; Etim et al., 2002; Ogbe et al., 2002; Sam et al., 2004, Uneke, 2004; Damen et al., 2007). Variation in the geohelminths recorded may be due to differences in the geographical location of the study. Despite variation in isolated parasites, Ova of Ascaris lumbricoides and Ova of Hookworm were common to all fruits and vegetables in all the studies. This could be due to the fact that these parasites can withstand a wide variety of adverse environmental conditions which could serve as an indication of water pollution as a result of indiscriminate defecation resulting in pollution of water and farmlands as observed by Damen et al., (2007). Faecal contamination of water sources used in crop irrigation is important sources of human infection, so contamination of fresh fruits and vegetables are of greatest concern (Orlandi et al, 2002). It was reported that in recent years, there has been an increase in the number of reported cases of food-borne illness linked with fresh fruits and vegetables due to contamination arising as a consequence of treating soil with organic fertilizers such as manure, sewage sludge and from irrigation water. The consumption of raw fruits and vegetables is a major way in the transmission of parasites of food borne illness because consumers would want to retain natural taste and preserve the nutrients to be derived from these fresh fruits and vegetables (Slifko et al, 2009). This in essence may increase food borne geohelminthic infections.

Comparing the two conventional techniques used in isolation of the geohelminths in this study, it was observed that sedimentation method had the highest recovery rate $(86.1 \%)$ while floatation method is $(13.9 \%)$. This is because most ova of geohelminths are heavy and therefore settles on the bottom of the tubes and can be missed using floatation technique.

\section{CONCLUSION}

The result from this study shows that there is high prevalence of geohelminths on edible fruits and vegetables from five different markets in rural villages of Ebonyi State, South East Nigeria. This poses a great risk of acquiring geohelminthic infections by eating improperly washed fruits and vegetables. Enlightenment programmes for the public on necessity of food sanitation and personal hygiene should be intensified. Government should also provide inorganic fertilizers at affordable rates to farmers in order to discourage the use of faeces as fertilizers.

\section{REFERENCES}

Adeyeba, O.A. and Akinlabi A.M (2002). Intestinal parasitic infections among school children in a rural community, South west Nigeria. Nigerian J. Parasitol., 23: 11-8.

Andrade, C., Palacio, A., Del Pogio, P., Jamoletti, P. and Gulleta, M (2001). Prevalence and intensity of soiltransmitted helminthiasis in the city of Porto Viejo Ecuador. Mem. Inst. Oswaldo Cruz., 96: 1075-9.

Adeboye, O.A. and Adedayo, A (2008). Nigeria under exploited indigenous fruits vegetables in era of climate. A review of scientific literature. Pp:1-4.

Arora, D.R. and Arora, B (2008). Medical Parasitology, 2nd Edition. Pp. 168180.

Brooker, S (2003). Soil - transmitted helminth infections and parasite control inSouth East Asia. South East Asian J. Trop. Med. Public Health, 34: 24-36.

Correale, J. and Farez, M (2007). Association between parasite infection and immune responses in multiple sclerosis. Annals of Neurology 61 (2): 97- 108.

Doyle, M.E (2003). Food-borne Parasites; A review of scientific literature, Food Research Institute, University of Wisconsin, Madison. Pp: 1-28. 
Damen, J.G., Banwat, E.B., Egah, D.Z., Allamana, J.A (2007). Parasitic Contamination of Vegetables in Jos, Nigeria. Annal of African Medicine, 6(2): 115-118.

De Silva, Brooker, N.R., Hotez, S., Montressor, J.I., Engels, A. and Savioli L (2003). Soil Transmitted helminth infections: Updating the global picture. Trends in parasitol 19:547-551.

Etim, S.E., Akpan, P.A., Abeshi, S., Offiom, O.E (2002). Intestinal helminth infections in children; Implications for helminth control using school based mass chemotherapy. Nigerian J. Parasitol., 23: 53-60.

Ezeamama, A.E., Friedman, J.F., Olveda, R.M., Acosta, L.P., Kurtis, J.D., Mor, V. and McGarvey, S (2005). Functional Significance of Low-IntensityPolyparasite Helminth Infections in Anaemia. $J$ Infect Dis 192(12):2160-70.

Naish, S., McCarthy, J., Williams, G.M (2004). Prevalence, intensity and risk factors for soil-transmitted helminth infection in a South Indian fishing village. Acta Tropica, 91:171-187.

Nock, I.H., Duniya, D. and Galadima, M (2003). Geohelminth eggs in soil and stool of pupils of some primary schools in Samaru, Zaria, Nigeria. Nigerian J. Parasitol., 24: 115-22.

Nyarango, R.M., Aloo, P.A., Kabiru, E.W. and Nyanchongi, B.O (2003). The risk of pathogenic parasitic infections in Kismi municipality. Kenya. BMC Public Health, 8.237 doilo 1186/1471-2458-8-237.
Orlandi, P.A., Chu, D.T., Bier, J.W., Jackson, G.J (2002). Parasites and food supply. Food Technol., 56(4): 7281.

Ogbe, M.G., Edet, E.E. and Isichei, M.N (2002). Intestinal helminth in primary school children in areas of operation of Shell Petroleum Development Company of Nigeria (SPDC), Western Division in Delta State. Nigerian J. Parasitol., 23: 3-10.

Phiri, K., Whitty, S., Graham, M., Sembatya, L (2000). Urban/rural differences in prevalence and risk factors for intestinal helminth infection in Southern Malawi. Annl. Trop. Med. Parasitol., 94: 381-7.

Sam - Wobo, S.O., Mafiana, C.F., Idowu, A.B (2004). Reinfection patterns of ascariasis among school children in Ogun State, Nigeria. Nigerian J. Parasit., 25: 7-13.

Silvia, R.D.S., Sylvia, E.F.V., Dariene, C.P., Ahie, M.S. and Gertrudes C (2007). Microbiological quality of minimally processed Vegetables sold in Porto Alegre, Brazil. Brazilian J. Microbiol., 38: 594-598.

Slifko, T.R., Smith, H.V. and Rose, J.B (2009). Emerging parasites Zoonoses associated with water and food. International J. Parasitol., 30: 1379- 1393.

Uneke, C.J (2004). Potential for geohelminth parasite transmission by raw fruits and vegetables in Nigeria; Implication for a risk profile. J. Nutrition and Environmental Medicine, 16(1): 59-68.

W.H.O (2008). Public Health Significance of intestinal parasitic infections. Bulletin of W.H.O., 65(5): 575-588. 